\title{
COMPARING A RANGE OF SIMPLE PLUME RISE MODELS AND MISR AEROSOL HEIGHT MEASUREMENTS
}

\author{
Shuo Wang, Chuyong Lin, Jason Blake Cohen* \\ School of Atmospheric Sciences, Sun Yat-Sen University, Zhuhai, 519082, China - (wangsh297@ mail2.sysu.edu.cn, \\ linchuyong@hotmail.com, jasonbc@alum.mit.edu)
}

Commission III, WG III/8

KEY WORDS: MISR, MOPITT, OMI, Plume Rise Model, Biomass Burning

\begin{abstract}
:
Rapid economic development leads to increasing sources of aerosols from both urban and biomass sources, which in turn have a significant impact on the atmosphere and the environment. There are significant differences however between urban sources, which tend to be emitted at low temperature, and biomass sources, which are co-emitted with a significant amount of heat. In this work, we first analyse the spatial and temporal distribution of aerosol height from 3.5 years of day-by-day global measurements of aerosol plume height from MISR from January 2008 through June of 2011). We next use a simple plume rise model (PRM) based on FRP and various meteorological variables both from MISR and from other data sources. We find that the PRM makes a reasonable reproduction of the MISR measurements in Western Siberia, Alaska, Central Canada, Argentina, and Eastern Europe, although it underestimates the MISR measurements everywhere. We compute the amount of aerosol above the boundary layer as well as its distribution, and find that the PRM can only come close to reproducing this in conditions which are dry and found in extra-tropical regions. In specific we find that there is a slight model improvement when we apply factors to the wind speed. In general, we find the results are optimized when wind speed is adjusted by $20 \%$ around the given mean value, and the vertical velocity is adjusted by $-20 \%$ to $+40 \%$ of the original value. The best fitting region, Argentina, is obtained with an RMS error (model biased low) of $0.39 \mathrm{~km}$, when the horizontal wind is unadjusted and the vertical wind is adjusted by $-20 \%$. We further find that the PRM approach is not applicable over those regions which have the highest magnitude of aerosol emissions, as detected by OMI and MOPITT measurements of NO2 and $\mathrm{CO}$ respectively, leading to future plans on how to correct for and improve this approach.
\end{abstract}

\section{INTRODUCTION}

Biomass burning occurs almost uniformly during the local dry season throughout all regions of the world, especially in rapidly-changing countries and those which are agriculturally-intensive(Kaufman et al. 1998, Turquety et al. 2007, Cohen et al. 2018). These changes are occurring on top of rapid urbanization. The observed air pollution in a region is the combination of these various different local and remotely transported sources(Cohen et al. 2011, Tosca et al. 2011). A clear understanding of the impacts of these various sources is complex in regions where there are multiple significant sources, since they occur across different spatial and temporal scales: urban sources near the surface and biomass burning sources high in the atmosphere(Singh et al. 2018).

Those sources emitted near the surface tend to stay closer to their point of emissions, while those sources which are first lofted to a significant height advect further and impact a different part of the atmosphere. Therefore, it is essential to understand the vertical profile of species freshly emitted into the atmosphere, if we are to better understand their fate and impact on the larger atmospheric system.

Wildfires every year are found to burn a significant fraction of global forests, grasslands and farmland, with the output being a significant discharge of aerosols, trace gases, and heat (Kaufman et al. 1998, Kahn et al. 2007, Tosca et al. 2011). Sources from fires affect the distribution of aerosol in a unique manner, since the co-emitted heat leads to lofting of the aerosols, with a significant amount even reaching into the free troposphere. Furthermore, significant differences in land type, meteorology, and duration and intensity of the local dry season lead to differences in the length and amount of emissions from biomass burning. These differences may span such situations as a large amount of emissions cover a short but intense time-frame, to conditions where smoldering continues for months on end. This diversity of sources and emissions under different conditions have led to a significant inter-annual and intra-annual variations of large-scale fire events(Cohen 2014). It is further thought that there are significant impacts between these changes and meteorology, although these connections are presently not well understood(Cohen et al. 2011, Cohen et al. 2018). Recent studies have shown that such extreme events are becoming more frequent (Kauffman et al. 2003, Achtemeier et al. 2011, van Donkelaar et al. 2011, Singh et al. 2018, Vernon et al. 2018).

In the past, biomass burning sources have been considered insignificant compared with local urban anthropogenic aerosol sources. However, new research has shown that fires contribute a significant amount towards even local loadings in many urban areas, not only just on the global scale, and that such effects may be observed regionally over times with an annual or higher frequency(Cohen et al. 2017, Cohen et al. 2018).

The current generation of models is poor in terms of reproducing the vertical distribution of atmospheric aerosols(Cohen et al. 2018, Val Martin et al. 2018). This is because they frequently do not capture the physics across the spatial and temporal scales required to drive the vertical rise. For example, plume rise models simulate the height mainly based on FRP and the atmospheric stability, while in reality we know that mountain winds, localized convection, and other forcing also play a significant role, as well as non-linear dynamics. This is why in general; simple plume rise models tend to underestimate aerosol height measurements. This is particularly so in terms of the amount injected into the free 
troposphere (Trentmann et al. 2006, Val Martin et al. 2012, Val Martin et al. 2018). In addition, it is known that under high AOD or cloudy conditions, it is hard or impossible to measure FRP, leading to a further underestimation of this key controlling factor for simple models.(Paugam et al. 2016, Val Martin et al. 2018).

On one hand, previous work by Ichoku and Ellison (2014) used time-integrated satellite measurements of FRP as a physical parameter to estimate the plume height, and found this to be more effective than using emissions factors. While a good step, their result did not consider the impact of the spatial and temporal variance in meteorological conditions. On the other hand, two previous attempts to study aerosol height over Southeast Asia and Australia were performed by Cohen et al. (2018)and Mims et al. (2010) and both considered meteorology, although they were limited to specific regions and land-use types. Our work is the first to address both approaches simultaneously.

We use a simple plume model based on first principles, and attempt to reproduce the measured MISR plume heights. We then quantify under what conditions and over what regions our simple model works well, and does not work well. Our analysis considers not only the difference in the mean, but also any bias in the extremes, so that we may better understand how to constrain the system across all realistic conditions that have been previously observed to impact a real aerosol plume's rise (Cohen et al. 2018). We specifically include more than 67000 pixels of data, spread out over 3 and half years.

\section{DATA AND METHODS}

\subsection{MISR Aerosol Measurements}

The Multi-angle Imaging SpectroRadiometer [MISR] flies on the Terra satellite and records images at 9 different angles in the 4 bands at $446 \mathrm{~nm}, 558 \mathrm{~nm}, 672 \mathrm{~nm}$, and $866 \mathrm{~nm}$ (Diner et al. 1998), allowing for the ability to distinguish different types of clouds, aerosol particles, and surfaces. The MISR INteractive eXplorer is used to combine MODIS fire point measurements (co-located on the Terra satellite(Freeborn et al. 2014)) with the plume heights from MISR, and provides wind speed and elevation at $1.1 \times 1.1 \mathrm{~km} 2$ (Nelson et al. 2013, Val Martin et al. 2018).We specifically use the daily plume heights and wind speed data, from MISR, as well as the fire radiative power (FRP)from MODIS. These measurements are only available under cloud free conditions, which therefore may lead to biases over regions where a significant amount of fires occur under cloudy conditions.

\subsection{Geography}

Worldwide biomass burning and deforestation have been undergoing tremendous changes over the past few decades. In this work, we focus on areas where the characteristics of the land type have changed rapidly, specifically, the fourteen regions shown in Table 1 . The computed mean and standard deviation of the MISR aerosol height measurements over each region show clearly a considerable amount of difference between these regions, attributed to differences in land surface type, climate, and various meteorological conditions.

\subsection{NCEP Reanalysis Data}

Meteorological data for the vertical temperature and pressure distribution have been obtained from the National Centers for
Environmental Prediction (NCEP) reanalysis database (version Reanalysis 1)(KALNAY 1996). These variables are then used to compute the gradient of temperature in vertical direction $(\mathrm{dT} / \mathrm{dz})$, the surface air Temperature, and the initial vertical velocity of smoke.

\begin{tabular}{|c|c|c|c|c|c|c|}
\hline & long 1 & long 2 & lat 1 & lat 2 & $\begin{array}{c}\text { Mean } \\
(\mathrm{km})\end{array}$ & SD \\
\hline $\begin{array}{c}\text { Central } \\
\text { Africa }\end{array}$ & 10 & 40 & 2 & 12 & 1.36 & 0.8 \\
\hline $\begin{array}{c}\text { Midwest } \\
\text { Africa }\end{array}$ & -15 & 5 & 6 & 15 & 0.9 & 0.42 \\
\hline $\begin{array}{c}\text { Southern } \\
\text { Africa }\end{array}$ & 14 & 40 & -20 & 0 & 1.7 & 0.56 \\
\hline $\begin{array}{l}\text { Central } \\
\text { Siberia } \\
\end{array}$ & 88 & 125 & 46.8 & 66 & 1.6 & 0.9 \\
\hline $\begin{array}{l}\text { Siberia and } \\
\text { Northern } \\
\text { China } \\
\end{array}$ & 125 & 135 & 45 & 65 & 1.27 & 0.97 \\
\hline $\begin{array}{l}\text { Eastern } \\
\text { Siberia } \\
\end{array}$ & 163.8 & 176.5 & 61 & 65.7 & 1.1 & 1 \\
\hline $\begin{array}{c}\text { Western } \\
\text { Siberia }\end{array}$ & 59 & 88 & 48 & 66 & 0.95 & 0.77 \\
\hline $\begin{array}{c}\text { Northern } \\
\text { Southeast } \\
\text { Asia }\end{array}$ & 92 & 108 & 11 & 24 & 1.57 & 1.03 \\
\hline $\begin{array}{l}\text { Northern } \\
\text { Australia }\end{array}$ & 121 & 147.2 & -20 & -11 & 0.9 & 0.62 \\
\hline Alaska & -156.5 & -133.8 & 60 & 68 & 1.57 & 0.91 \\
\hline $\begin{array}{l}\text { Central } \\
\text { Canada } \\
\end{array}$ & -120 & -94.5 & 54.5 & 64 & 1.97 & 1.26 \\
\hline $\begin{array}{c}\text { South } \\
\text { America } \\
\end{array}$ & -70 & -40 & -22 & -4 & 0.97 & 0.66 \\
\hline Argentina & -66 & -55 & -31 & -22 & 0.69 & 0.7 \\
\hline $\begin{array}{l}\text { Eastern } \\
\text { Europe }\end{array}$ & 30 & 59 & 46.8 & 57.5 & 1.41 & 1.05 \\
\hline
\end{tabular}

Table 1. Latitude and Longitude boundaries of the 14 regions studied in this work.

\subsection{Plume Rise Model}

Traditionally, plumes rise models have been associated with air pollution emitted from hot stacks. In this work, we use a similar approach based on the heat flux co-emitted by each fire. The total heat flux and latent heat flux, when combined with the area of each fire in turn determines the plume buoyancy(Val Martin et al. 2012), in an approximation based on.thermal dynamics. The empirical plume rise model to reproduce the height of aerosol plumes which over fire hot spots measured by MISR, is slightly different based on whether the vertical and horizontal meteorology is dominated at that place and time by buoyancy or momentum. Since the plume rise is rapid, the connection between the localized meteorological and fire conditions can be quickly parameterized and applied in large-scale modeling systems. This allows for an effective transport from the surface to the lower-free troposphere, where long-distance transport of aerosols is possible. There are some issues with this approach. Firstly, large areas of cloud cover may lead to an underestimate of FRP or even the complete missing of fires (Kauffman et al. 2003). Secondly, reanalysis does not match well with regions that have strong mountain derived winds, or pollution-induced meteorological fields under very high AOD conditions (Achtemeier et al. 2011). Thirdly, our work does not take into account the long-distance transport of aerosols from adjacent areas, or convection induced by heating induced by the aerosols themselves. 


\subsection{Analytics and Statistics}

We jointly analyze the mean, the variation, and the extremes of the vertical distribution over each region. The purpose is to observe that the sources of aerosol plumes with similar mean heights may have very different variances, or may in general be similar, but have a set of extreme conditions which are quite different.

Furthermore, we employ a set of constant multiplicative wind spee factors as a means of testing the sensitivity of the model to the meteorology provided respectively by either MISR or NCEP These values are applied in steps of 0.2 over the range from 0.8 to 1.6. This factor is applied both to the vertical wind as well as the horizontal wind, although it is not applied to both simultaneously. Although there is some connection between uncertainty in the wind and in the vertical temperature gradient, we do not consider this here, since there is no way simple way to couple this using reanalysis meteorology(Cohen et al. 2018).

\section{RESULTS}

\subsection{Spatial-Temporal Distribution of the MISR Data}

The spatial distribution of the climatological mean and the standard deviation of the MISR aerosol plume height in each $10 \mathrm{~km} \times 10 \mathrm{~km}$ grid is given in Figure 1. Another way to look at this data is to analyze the vertical distribution over each region of interest. We have computed the amount of the total MISR points found within each $100 \mathrm{~m}$ layer height, i.e. $0 \mathrm{~m}$ to $100 \mathrm{~m}$, $100 \mathrm{~m}$ to $200 \mathrm{~m}$, etc. as given in Table 2 . These techniques allow us to understand and differentiate the different regions on the basis of their spatial and vertical climatology. We find that these results are different from previous attempts including those commonly accepted by the community as the gold standard.

As displayed in Figure 1a we can clearly analyze which areas have the largest impact on aerosol height, which specifically include southern and Central Africa, Central South America, Siberia, Northern Southeast Asia, Canada, and Northern Australia. However, there are some regions over which MISR has not captured what were otherwise expected to be areas with a significant aerosol vertical source, in specific those regions in the Sichuan Basin, Indonesia, and India. The reason may be due to meteorological factors, because pollutants emitted from local sources are mixed in with biomass burning plumes in the regions. Another possibility is that high levels of clouds that occur at the same time as the biomass burning in these regions may be masking their signal. Another consequence of these two rationales is that there are some regions where we find there are too many plumes, such as in Northern Australia, Eastern Europe, Eastern China, and the Northeastern USA, which may in fact be related to downwind transport from these areas, or mis-characterization of surface heat sources which are not from fires.

We determine that a significant amount of aerosol mass exists in the free troposphere over each region. Assuming the measured daily average boundary layer height can be represented by the range from $1000 \mathrm{~m}$ to $2000 \mathrm{~m}$ (Guo et al. 2016, Cohen et al 2018), and has a central value of $1500 \mathrm{~m}$, we compute the fraction of the aerosol loading in the free troposphere of the regions, respectively (with all values representing a percent above the respective boundary layer height): $(31,57,12)$; $(64,35,1) ; \quad(5.9,70,24.1) ; \quad(22,51,27) ; \quad(37,55.7,7.3) ;(50,45,5)$; (64.5,30,5.5); (37,36,27); (64,32,3.9); (29,46,25); (22,36,42);
$(63,32,5) ;(84,11,5)$; and $(39,44,17)$, respectively. This set of results is important in three ways, first that in all regions, the amount in the free troposphere is more than in previous studies (which indicated the large majority of smoke remained within the boundary layer(Cohen et al. 2018)); secondly that there is a significant difference between different regions when the boundary layer is high, which will cause considerable divergence when the current generation of models are compared with measurements; and third, that the wide variation will likely cause significant retrieval errors in aerosol products, including AOD.

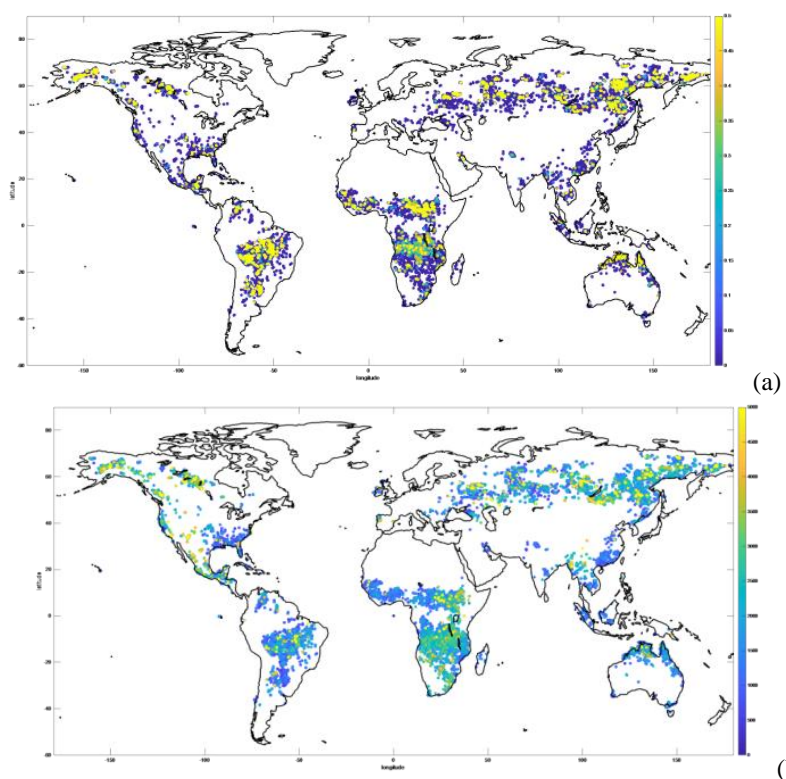

(b)

Figure 1. Climatological mean (a) and Climatological normalized standard deviation (b) of the daily average MISR plume height measurements, from January 2008 through July 2011.

With respect to the case of Central Canada, we find that both the boundary layer and the free troposphere both have a roughly similar amount of aerosol (58.3\% in the boundary layer and 39\% in the lower free troposphere). What is unique is that over this region, there is also a significant amount of aerosol $(2.7 \%)$ found in the middle and upper free troposphere above $5 \mathrm{~km}$. The results in this region are consistent with primary forests being burnt at very high temperature.

\begin{tabular}{|c|c|c|c|c|c|c|}
\hline & $0-1 \mathrm{k}$ & $1 \mathrm{k}-2 \mathrm{k}$ & $2 \mathrm{k}-3 \mathrm{k}$ & $3 \mathrm{k}-4 \mathrm{k}$ & $4 \mathrm{k}-5 \mathrm{k}$ & $>5 \mathrm{k}$ \\
\hline $\begin{array}{c}\text { Central } \\
\text { Africa }\end{array}$ & $30.9 \%$ & $56.9 \%$ & $9.9 \%$ & $1.7 \%$ & $0.3 \%$ & $0.3 \%$ \\
\hline $\begin{array}{c}\text { Midwest } \\
\text { Africa }\end{array}$ & $64.4 \%$ & $34.8 \%$ & $0.6 \%$ & $0.1 \%$ & $0.0 \%$ & $0.1 \%$ \\
\hline $\begin{array}{c}\text { Southern } \\
\text { Africa }\end{array}$ & $5.8 \%$ & $69.8 \%$ & $22.9 \%$ & $1.2 \%$ & $0.2 \%$ & $0.1 \%$ \\
\hline $\begin{array}{c}\text { Central } \\
\text { Siberia }\end{array}$ & $21.8 \%$ & $50.8 \%$ & $22.0 \%$ & $4.0 \%$ & $0.8 \%$ & $0.7 \%$ \\
\hline $\begin{array}{c}\text { Siberia } \\
\text { and } \\
\text { Northern } \\
\text { China }\end{array}$ & $36.8 \%$ & $55.7 \%$ & $5.9 \%$ & $0.4 \%$ & $0.2 \%$ & $0.9 \%$ \\
\hline $\begin{array}{c}\text { Eastern } \\
\text { Siberia }\end{array}$ & $50.2 \%$ & $44.7 \%$ & $3.3 \%$ & $0.7 \%$ & $0.1 \%$ & $0.9 \%$ \\
\hline $\begin{array}{c}\text { Western } \\
\text { Siberia }\end{array}$ & $64.7 \%$ & $29.8 \%$ & $3.9 \%$ & $0.8 \%$ & $0.3 \%$ & $0.4 \%$ \\
\hline
\end{tabular}




\begin{tabular}{|c|c|c|c|c|c|c|}
\hline $\begin{array}{c}\text { Northern } \\
\text { Southeast } \\
\text { Asia }\end{array}$ & $37.1 \%$ & $35.6 \%$ & $17.0 \%$ & $7.3 \%$ & $2.4 \%$ & $0.6 \%$ \\
\hline $\begin{array}{c}\text { Northern } \\
\text { Australia }\end{array}$ & $64.3 \%$ & $31.8 \%$ & $2.6 \%$ & $1.2 \%$ & $0.1 \%$ & $0.1 \%$ \\
\hline Alaska & $29.3 \%$ & $45.8 \%$ & $17.8 \%$ & $5.6 \%$ & $1.1 \%$ & $0.5 \%$ \\
\hline $\begin{array}{c}\text { Central } \\
\text { Canada }\end{array}$ & $22.3 \%$ & $36.0 \%$ & $25.5 \%$ & $9.7 \%$ & $3.9 \%$ & $2.7 \%$ \\
\hline $\begin{array}{c}\text { South } \\
\text { America }\end{array}$ & $63.1 \%$ & $31.4 \%$ & $4.4 \%$ & $0.7 \%$ & $0.1 \%$ & $0.2 \%$ \\
\hline Argentina & $83.8 \%$ & $11.1 \%$ & $2.3 \%$ & $2.3 \%$ & $0.6 \%$ & $0.0 \%$ \\
\hline $\begin{array}{c}\text { Eastern } \\
\text { Europe }\end{array}$ & $38.5 \%$ & $44.1 \%$ & $9.7 \%$ & $4.5 \%$ & $2.7 \%$ & $0.5 \%$ \\
\hline
\end{tabular}

Table 2. Statistical summary of different height of MISR measurements during 2008-2011, over different regions

Furthermore, the vast majority of the other locations we cannot as readily draw a statistically significant conclusion about the nature of the heights. We find that in many cleaner regions (as determined by the profiles of $\mathrm{NO} 2$ from $\mathrm{OMI}$ ) specifically in Siberia, Alaska, and Australia, the magnitude of the standard deviation of height is extremely large when compared with the plume height, making characterization complex. These regions sometimes have very severe fires, and at other times have low-temperature fires. However, we can observe from the NO2 profiles that the emissions do not vary greatly between the total emissions levels found under the different sets of aerosol height conditions. This tells us that a deeper understanding is required in order to understand the vertical aerosol distribution.

On the other hand, in those regions which have a higher loading of pollutants, such as in Central Africa, Southeast Asia, South America, etc. there is a more complex set of aerosol sources. These regions have a significant amount of biomass burning, but also have a rapidly increasing amount of urbanization and high population density. These urban sources will tend to mostly occur within the boundary layer. Therefore, we find that some of these regions have a higher standard deviation in aerosol height and hence are harder to characterize. However, a subset of these regions, in specific Southeast Asia and Western Central Africa, have a lower standard deviation and are found to have a very consistent aerosol height distribution during the latter parts of the local dry season. In all of these sets of cases however, we find that the simple model based on FRP and meteorology still does not perform well. This has a known theoretical basis however. Firstly, because these regions tend to have clouds at the same time as the burning. And secondly because in the case where there is a significant amount of absorbing aerosol near the top of boundary layer and extending into the lower free troposphere, its interaction with radiation is much stronger, and the lifetime of the aerosol will be enhanced. Furthermore, there may be interactions between the aerosols themselves with the dynamics, possibly providing a feedback further narrowing the aerosol plume height.

\subsection{Sensitivity Tests of Wind Factor on Plume Rise Model}

The statistical results of the plume rise model when applied to all of the regions from Table 3 in the respective order are found to have an aggregated mean height (and standard deviation) $0.58 \mathrm{~km}(0.23 \mathrm{~km}), \quad 0.87 \mathrm{~km}(0.89 \mathrm{~km})$, $0.68 \mathrm{~km}(0.34 \mathrm{~km}), \quad 0.79 \mathrm{~km}(0.95 \mathrm{~km})$, $0.64 \mathrm{~km}(0.29 \mathrm{~km}), \quad 1.39 \mathrm{~km}(3.03 \mathrm{~km})$ $0.80 \mathrm{~km}(0.64 \mathrm{~km})$ $0.73 \mathrm{~km}(0.38 \mathrm{~km})$, $1.73 \mathrm{~km}(2.19 \mathrm{~km})$ $0.50 \mathrm{~km}(0.21 \mathrm{~km}), \quad 0.65 \mathrm{~km}(0.25 \mathrm{~km}), \quad$ and $\quad 1.27 \mathrm{~km}(2.67 \mathrm{~km})$.
Across all of these results, we find that the average modeled height is always lower than the average height of the measurements, with the range from $0.04 \mathrm{~km}$ to $0.83 \mathrm{~km}$. The regions with the best average height representation are found in Argentina $(0.04 \mathrm{~km})$, East Europe $(0.14 \mathrm{~km})$, West Siberia $(0.16 \mathrm{~km})$, Alaska $(0.18 \mathrm{~km})$, Central Canada $(0.24 \mathrm{~km})$ and Northern Australia $(0.26 \mathrm{~km})$. Those regions with a high average standard deviation are not considered further in this work.

A very interesting point is that most of the regions which have a reasonable average representation by the plume rise model are found at middle and high latitudes, and are regions which are generally cloud-free. This means that localized effects such as the fire-induced heating are more important, since they do not as frequently experience large-scale deep convection (like the tropics) and they also do not have as much bias in terms of FRP measurements being hindered (i.e. by cloud cover). Both these aspects lead to a more simplified dynamical plume mode being more suitable. The opposite is expected to be true in the regions which are found to have the largest difference between the mean height and plume rise model representation, such as in Africa, Southeast Asia, and the Amazon.

\begin{tabular}{|c|c|c|c|c|c|}
\hline & $\begin{array}{l}\text { Western } \\
\text { Siberia }\end{array}$ & Alaska & $\begin{array}{l}\text { Central } \\
\text { Canada }\end{array}$ & Argentina & $\begin{array}{l}\text { Eastern } \\
\text { Europe }\end{array}$ \\
\hline $\begin{array}{c}\text { MISR } \\
\text { data }\end{array}$ & $\begin{array}{c}0.95 \\
(0.77) \\
\end{array}$ & $\begin{array}{c}1.57 \\
(0.91) \\
\end{array}$ & $\begin{array}{c}1.97 \\
(1.26)\end{array}$ & $\begin{array}{c}0.69 \\
(0.70) \\
\end{array}$ & $\begin{array}{c}1.41 \\
(1.05)\end{array}$ \\
\hline $\begin{array}{l}\text { Plume } \\
\text { Model }\end{array}$ & $\begin{array}{c}0.79 \\
(0.95)\end{array}$ & $\begin{array}{c}1.39 \\
(3.03)\end{array}$ & $\begin{array}{c}1.73 \\
(2.19)\end{array}$ & $\begin{array}{c}0.65 \\
(0.25)\end{array}$ & $\begin{array}{c}1.27 \\
(2.67)\end{array}$ \\
\hline$V X=0.8$ & $\begin{array}{c}0.71 \\
(0.80) \\
\end{array}$ & $\begin{array}{c}1.25 \\
(2.56) \\
\end{array}$ & $\begin{array}{c}1.48 \\
(1.84) \\
\end{array}$ & $\begin{array}{c}0.60 \\
(0.24) \\
\end{array}$ & $\begin{array}{c}1.12 \\
(2.25) \\
\end{array}$ \\
\hline $\mathrm{VX}=1.2$ & $\begin{array}{c}0.86 \\
(1.09)\end{array}$ & $\begin{array}{c}1.52 \\
(3.48)\end{array}$ & $\begin{array}{c}1.96 \\
(2.51)\end{array}$ & $\begin{array}{c}0.69 \\
(0.27)\end{array}$ & $\begin{array}{c}1.41 \\
(3.07)\end{array}$ \\
\hline $\mathrm{VX}=1.4$ & $\begin{array}{c}0.92 \\
(1.23) \\
\end{array}$ & $\begin{array}{c}1.63 \\
(3.91) \\
\end{array}$ & $\begin{array}{c}2.19 \\
(2.83) \\
\end{array}$ & $\begin{array}{c}0.73 \\
(0.29) \\
\end{array}$ & $\begin{array}{c}1.54 \\
(3.45) \\
\end{array}$ \\
\hline $\mathrm{VX}=1.6$ & $\begin{array}{c}0.98 \\
(1.36)\end{array}$ & $\begin{array}{c}1.74 \\
(4.33)\end{array}$ & $\begin{array}{c}2.41 \\
(3.13)\end{array}$ & $\begin{array}{c}0.76 \\
(0.30)\end{array}$ & $\begin{array}{c}1.67 \\
(3.82)\end{array}$ \\
\hline $\mathrm{UX}=0.8$ & $\begin{array}{c}0.89 \\
(1.20)\end{array}$ & $\begin{array}{c}1.58 \\
(3.80)\end{array}$ & $\begin{array}{c}2.13 \\
(2.75)\end{array}$ & $\begin{array}{c}0.70 \\
(0.28)\end{array}$ & $\begin{array}{c}1.49 \\
(3.35)\end{array}$ \\
\hline $\mathrm{UX}=1.2$ & $\begin{array}{c}0.71 \\
(0.79)\end{array}$ & $\begin{array}{c}1.26 \\
(2.52)\end{array}$ & $\begin{array}{c}1.46 \\
(1.81)\end{array}$ & $\begin{array}{c}0.61 \\
(0.24)\end{array}$ & $\begin{array}{c}1.12 \\
(2.22)\end{array}$ \\
\hline $\mathrm{UX}=1.4$ & $\begin{array}{c}0.66 \\
(0.67)\end{array}$ & $\begin{array}{c}1.16 \\
(2.15)\end{array}$ & $\begin{array}{c}1.27 \\
(1.55)\end{array}$ & $\begin{array}{c}0.58 \\
(0.23)\end{array}$ & $\begin{array}{c}1.00 \\
(1.90)\end{array}$ \\
\hline $\mathrm{UX}=1.6$ & $\begin{array}{c}0.62 \\
(0.59)\end{array}$ & $\begin{array}{c}1.08 \\
(1.88)\end{array}$ & $\begin{array}{c}1.13 \\
(1.35)\end{array}$ & $\begin{array}{c}0.55 \\
(0.22)\end{array}$ & $\begin{array}{c}0.92 \\
(1.66)\end{array}$ \\
\hline
\end{tabular}

Table 3. Statistics of (top row) measured MISR plume heights and (standard deviations) using daily data from 2008 to 2011; (second row) the plume rise model; and various sensitivity tests with the model as a function of vertical (VX) and horizontal (YX) velocity.

One important meteorological factor in terms of plume rise modeling is the wind speed, as shown in Table 3. Initially wind speed was assumed to be constant uniform over the entire vertical rise of the plume. However, given how high these plumes rise, such an assumption may no longer be valid, as winds in the lower free troposphere are frequently different from in the boundary layer. Therefore, a sensitivity analysis can help us to understand the impact of such assumptions on the model's ability to predict the plume heights. For Argentina, East Europe and West Siberia, the change of wind speed factor has little impact on the RMS (about 0.4, 0.8 and 0.7 respectively for Argentina, East Europe and West Siberia). But the best-fit wind factors (in terms of root mean square error (RMS)) are found to specifically be VX $=1.6, \mathrm{RMS}=1.10 \mathrm{~km}$ for Central Canada and 
$\mathrm{VX}=1.2, \mathrm{RMS}=0.66 \mathrm{~km}$ and $\mathrm{UX}=0.8, \mathrm{RMS}=0.66 \mathrm{~km}$ for West Siberia.

\subsection{Modeled Aerosol Vertical Distribution}

A comparison of the day-to-day modeled and measured heights for the best-fit regions is given in Figure 2. Firstly, most of the modeled values are found to fall within one standard deviation of the measured mean daily value over each region (the length of the error bars in the plot). Secondly, it is observed that the vast majority of the data is aggregated around certain times of the year as a function of each site, which in all cases belongs to the local dry season when FRP and stereo measurements are available. Thirdly, a significant amount of the total RMS error occurs when there are either extremely high measured values over $5 \mathrm{~km}$ (indicating pyro-convection or other non-standard vertical atmospheric conditions) or when the modeled height is three times higher than the measured height and at the same time the measurement is located below $0.5 \mathrm{~km}$ (indicating that FRP is not the reason why the model is wrong).

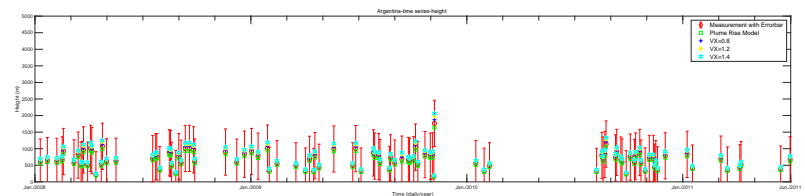

(a)

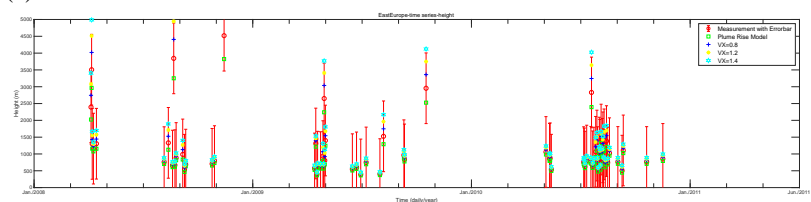

(b)

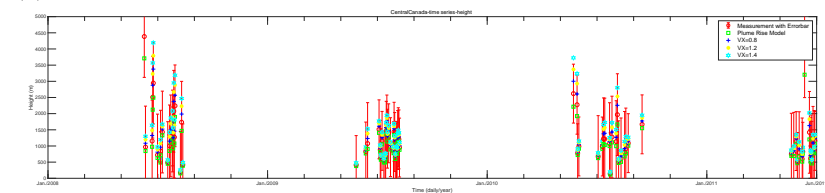

(c)

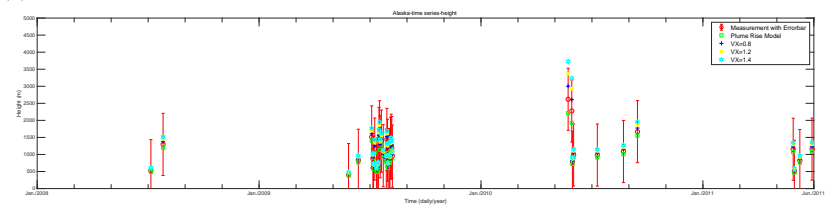

(d)

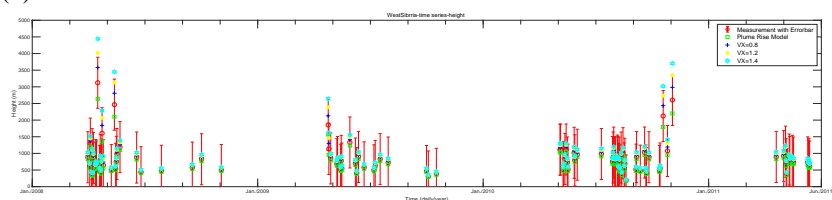

(e)

Figure 2. Comparison the time series of wind speed factors height, plume rise model height and measured height over five best-fit regions (a) Argentina; (b) East Europe; (c) Central Canada; (d) Alaska; (e) West Siberia.

\section{DISCUSSION AND CONCLUSION}

This work uses new data on the vertical distribution of aerosols and combines this with a simple plume rise model to estimate the vertical distribution of smoke plumes. We find that applying measurements of the daily mean and standard deviation of data over the whole world from MISR allows us to derive useful and meaningful characteristics of the vertical plume height over regions without significant cloudiness. We find that in non-tropical forests, such as Alaska, Argentine, and Siberia, the overall characteristics are stable, with a few dominating extreme events, including events lofting aerosols into the stratosphere. Over Africa and parts of Southeast Asia, we find that aerosols likely come from multiple sources include biomass burning, anthropogenic sources, and long-range transport, so that a significant amount of the total plume is found both below the boundary layer during part of the year, and above the boundary layer during other parts of the year.

While trying to understand the major cause of model uncertainty, we have discovered that uncertainties in the measured wind speed are significant. Over some regions, the model performs better when error in the wind measurements are random in nature, such as in Argentina and Central Canada. Over other regions, we find that a bias in wind speed allows for a best fit with measurements, including in Western Siberia, Alaska, and Eastern Europe. In terms of the most extreme events, our model when used with an enhanced wind factor of $\mathrm{VX}=1.4$, is capable of reproducing the timing of the enhanced higher plume heights that are observed in Western Siberia (April 2008), Eastern Europe (September 2008), Alaska (May 2009), and Argentina (November 2009). Although this wind factor is not uniform everywhere and merely applying it uniformly will lead to other occurrences where the measured heights are severely overestimated. Over the rest of the world, the simple plume model approach is found to not be appropriate under any set of reasonable wind-speed conditions.

Conversely to other findings, we have not identified any statistically valid trend in the aerosol height distribution over the time series from 2008 to 2011. This indicates that a combination of the emissions and underlying processes controlling the vertical distribution have not changed much over the time of interest. Simultaneously, we also have determined contrary to the literature that the most extreme values measured (both for plumes above $5 \mathrm{~km}$ and below $500 \mathrm{~m}$ ) are not well reproduced by the plume rise model, even though the FRP values have been measured in cloud-free conditions, indicating that there are other factors besides bias of the FRP and wind speed which are driving these more extreme conditions.

\section{REFERENCES}

Achtemeier, G. L., Goodrick S. A., Y. Liu, F. Garcia-Menendez, $\mathrm{Hu}$, Y., Odman, M. T., 2011. Modeling Smoke Plume-Rise and Dispersion from Southern United States Prescribed Burns with Daysmoke. Atmosphere, 2(3), 358-388.

Cohen, J. B., 2014. Quantifying the occurrence and magnitude of the Southeast Asian fire climatology. Environmental Research Letters, 9(11), 114018.

Cohen, J. B., Lecoeur, E., Ng, D. H. L., 2017. Decadal-scale relationship between measurements of aerosols, land-use change, and fire over Southeast Asia. Atmospheric Chemistry \& Physics, 17(19), 26895-26957.

Cohen, J. B., Ng, D. H. L., Lim, A. W. L., Xin, R. C. J., 2018. Vertical distribution of aerosols over the Maritime Continent during El Niño. Atmospheric Chemistry \& Physics, 18(10), 7095-7108.

Cohen, J. B., Prinn, R. G., Wang C., 2011. The impact of detailed urban-scale processing on the composition, distribution, and radiative forcing of anthropogenic aerosols. Geophysical Research Letters, 38(10),264-265. 
Diner, D. J., Beckert, J. C., Reilly, T. H., Bruegge, C. J., Conel, J. E., Kahn, R. A., Martonchik, J. V., Ackerman, T. P., Davies, R., Gerstl, S. A. W., Gordon, H. R., Muller, J. P., Myneni, R. B., Sellers, P. J., Pinty, B., Verstraete, M. M., 1998. Multi-angle Imaging SpectroRadiometer (MISR) instrument description and experiment overview. IEEE Transactions on Geoscience and Remote Sensing, 36(4), 1072-1087.

Freeborn, P. H., Wooster, M. J., Roy D. P., Cochrane M. A., 2014. Quantification of MODIS fire radiative power (FRP) measurement uncertainty for use in satellite- based active fire characterization and biomass burning estimation. Geophysical Research Letters, 41(6), 1988-1994.

Guo, J., Deng, M., Lee, S. S., Wang, F., Li, Z., Zhai, P., Liu, H., Lv, W., Yao W., Li X., 2016. Delaying precipitation and lightning by air pollution over the Pearl River Delta. Part I: Observational analyses. Journal of Geophysical Research Atmospheres, 121(11), 6472-6488.

Ichoku, C., Ellison L., 2014. Global top-down smoke-aerosol emissions estimation using satellite fire radiative power measurements. Atmospheric Chemistry and Physics, 14(13), 6643-6667.

Kahn, R. A., Li, W. H., Moroney, C., Diner, D. J., Martonchik, J. V., Fishbein, E., 2007. Aerosol source plume physical characteristics from space-based multiangle imaging. Journal of Geophysical Research-Part D-Atmospheres, 112, 1-20.

Kalnay, E., 1996. NCEP/NCAR 40-year reanalysis project. Bulletin of the American Meteorological Society, 77(3), 437-472.

Kauffman, J. B., Steele, M. D., Cummings, D. L., Jaramillo, V. J., 2003. Biomass dynamics associated with deforestation, fire, and, conversion to cattle pasture in a Mexican tropical dry forest Forest Ecology and Management, 176(1-3), 1-12.

Kaufman, Y. J., Justice, C. O., Flynn, L. P., Kendall, J. D., Prins, E. M., Giglio, L., Ward, D. E., Menzel W. P., Setzer A. W., 1998. Potential global fire monitoring from EOS-MODIS. Journal of Geophysical Research, 103(D24), 32215-32238.

Mims, S. R., Kahn, R. A., Moroney, C. M., Gaitley, B. J., Nelson, D. L., Garay M. J., 2010. MISR Stereo Heights of Grassland Fire Smoke Plumes in Australia. IEEE Transactions on Geoscience and Remote Sensing, 48(1), 25-35.

Nelson, D. L., Garay, M. J., Kahn R. A., Dunst, B. A., 2013. Stereoscopic Height and Wind Retrievals for Aerosol Plumes with the MISR INteractive eXplorer (MINX). Remote Sensing, 5(9), 4593-4628.

Paugam, R., Wooster, M., Freitas S., Martin M. V., 2016. A review of approaches to estimate wildfire plume injection height within large-scale atmospheric chemical transport models. Atmospheric Chemistry and Physics, 16(2), 907-925.

Singh, N., Banerjee, T., Raju, M. P., Deboudt, K., Sorek-Hamer, M., Singh, R. S., Mall, R. K., 2018. Aerosol chemistry, transport, and climatic implications during extreme biomass burning emissions over the Indo-Gangetic Plain. Atmospheric Chemistry and Physics, 18(19), 14197-14215.
Tosca, M. G., Randerson, J. T., Zender, C. S., Nelson, D. L., Diner, D. J., Logan, J. A., 2011. Dynamics of fire plumes and smoke clouds associated with peat and deforestation fires in Indonesia. Journal of Geophysical Research-Atmospheres, 116(D8).

Trentmann, J., Luderer, G., Winterrath, T., Fromm, M. D., Servranckx, R., Textor, C., Herzog, M., Graf, H. F., Andreae, M. O., 2006. Modeling of biomass smoke injection into the lower stratosphere by a large forest fire (Part I), reference simulation. Atmospheric Chemistry and Physics, 6, 5247-5260.

Turquety, S., Logan, J. A., Jacob, D. J., Hudman, R. C., Leung, F. Y., Heald, C. L., Yantosca, R. M., Wu, S.,. Emmons, L. K, Edwards, D. P., Sachse, G. W., 2007. Inventory of boreal fire emissions for North America in 2004: Importance of peat burning and pyroconvective injection. Journal of Geophysical Research-Atmospheres, 112(D12).

Van Donkelaar, A., Martin, R. V., Levy, R. C., Da Silva, A. M., Krzyzanowski, M., Chubarova, N. E., Semutnikova, E., Cohen, A. J. 2011. Satellite-based estimates of ground-level fine particulate matter during extreme events, A case study of the Moscow fires in 2010. Atmospheric Environment, 45(34), $6225-6232$

Vernon, C. J., Bolt, R., Canty, T., Kahn, R. A. 2018. The impact of MISR-derived injection height initialization on wildfire and volcanic plume dispersion in the HYSPLIT model. Atmospheric Measurement Techniques, 11(11), 6289-6307.

Revised August 2019 